\title{
Bioaugmentation with Petroleum-Degrading Consortia Has a Selective Growth-Promoting Impact on Crop Plants Germinated in Diesel Oil-Contaminated Soil
}

\author{
Weronika Graj • Piotr Lisiecki • Alicja Szulc • \\ Lukasz Chrzanowski • Joanna Wojtera-Kwiczor
}

Received: 15 January 2013 / Accepted: 25 July 2013 /Published online: 21 August 2013

(C) The Author(s) 2013. This article is published with open access at Springerlink.com

\begin{abstract}
Rhizoremediation is a complex type of green clean-up technology that involves both plants and the rhizosphere-associated microorganisms to decompose hazardous compounds. The success of the strategy strongly depends on plant tolerance towards the pollutant, as well as plant's interactions with the rhizospheric microbes. The microorganisms may be stimulated by the secreted root exudates, which results in an increased breakdown of contaminants in the rhizosphere. The main goal of this study was to establish a potential rhizoremediation combination for a diesel-polluted site. Inoculation of plant roots or seeds with indigenous rhizospheric populations is a common approach in the rhizoremediation. However, we introduced hydrocarbondegrading consortia (M10, R3, and K52) that were previously isolated from crude oil-contaminated soil instead of indigenous microbes. Bioaugmentation with these petroleum degraders was applied to screen four high
\end{abstract}

Electronic supplementary material The online version of this article (doi:10.1007/s11270-013-1676-0) contains

supplementary material, which is available to authorized users.

W. Graj · J. Wojtera-Kwiczor $(\bowtie)$

Department of Biochemistry, Institute of Molecular Biology

and Biotechnology, Faculty of Biology, Adam Mickiewicz

University in Poznań,

Umultowska 89, 61-614 Poznań, Poland

e-mail: jwojtera@amu.edu.pl

P. Lisiecki $\cdot$ A. Szulc $\cdot$ Ł. Chrzanowski

Institute of Chemical Technology and Engineering, Poznan

University of Technology,

Pl. M. Sklodowskiej-Curie 2, 60-965 Poznań, Poland biomass crop species (Indian mustard, alfalfa, high erucic acid rapeseed, HEAR, and low erucic acid rapeseed, LEAR) for their tolerance towards diesel oil. At no pollution, a promoting effect of M10 bacteria could be observed on germination and root elongation of all plant species. Moreover, M10 consortiums increased the germination index at 6,000 $\mathrm{mg}$ diesel oil per kilogram dry soil in the case of Indian mustard, alfalfa, and HEAR. The latter species was found to increment its dry weight upon bioaugmentation with M10 bacteria and all diesel oil treatments $(6,000$ and $24,000 \mathrm{mg}$ diesel oil per kilogram dry soil). The initial results indicate HEAR and the M10 bacterial consortium as a promising plant-microbe tandem for a long-term rhizoremediation process.

Keywords Bioaugmentation · Petroleum degraders . Petroleum hydrocarbons · Petroleum phytotoxicity . Rhizoremediation

\section{Introduction}

Diesel oil is a common product of crude oil distillation with a very complex composition. It consists mainly of low molecular weight alkanes and polycyclic aromatic hydrocarbons (PAHs) (Bona et al. 2011). The fate of the latter compounds in nature may be of great humanhealth importance, since PAHs have been considered toxic for plants and carcinogenic for people (Alkio et al. 2005; Reynoso-Cuevas et al. 2008; Bona et al. 2011). In case of an uncontrolled industrial leakage, 
diesel oil and its constituents might act as a persistent water and soil pollutant. Alkio et al. (2005) reported many adverse effects of phenanthrene on the model plant Arabidopsis thaliana, including reduction of stem and root growth, deformed trichomes and reduced radicular hairs. According to Nogueira et al. (2011), petroleum compounds can decrease the availability of water, oxygen, and nutrients in soil which in consequence, may decline the rate of seed germination. Apparently, the hydrocarbon film created on the seed surface prevents the delivery of water and oxygen to the developing embryo (Adam and Duncan 2002). At the cellular level, plants exposed to diesel oil show signs of oxidative stress, as well as degradation of chlorophyll. Moreover, an increase in the production of stress-related phytohormones, accumulation of toxic substances in plant tissues and, in consequence, a decrease in their total size and biomass production are also observed (Bona et al. 2011; Ahammed et al. 2012).

Environmental contamination with petroleum hydrocarbons is an inevitable problem that strikes many geographical regions to a variable extent depending on the local environmental law. Due to this fact, alternative biological clean-up methods, such as bioremediation and phytoremediation, have raised much interest in the last two decades. Moreover, a reasonable combination of both techniques is reflected by an emerging number of studies that utilize the natural degradation abilities of plants and plant-associated microorganisms to remove organic pollutants or heavy metals from the polluted environment (Liste and Felgentreu 2006; Gaskin et al. 2008; Lin et al. 2008; Chauhan and Rai 2009; Tang et al. 2010). Rhizoremediation is a successful, cost-effective and environmentally friendly approach that is based on pollutant degradation to non- or less-toxic compounds by microorganisms in the rhizosphere. These root-associated microbes are naturally equipped with pollutant-degrading enzymes (e.g., peroxidases, dioxygenases, P450 monooxygenases, laccases, phosphatases, dehalogenases, and nitroreductases) (Kuiper et al. 2004; Böltner et al. 2008; Wenzel 2008). Common cooperation among plants and the rhizosphere-associated bacteria is known as a "rhizosphere effect," where plants provide bacteria with nutrients (sugars, amino acids, organic acids) in form of root exudates and stimulate microorganisms to a more effective decomposition of xenobiotics (Böltner et al. 2008; Gaskin et al. 2008; Gerhardt et al. 2009). However, a single microbe does not generally possess all requiring enzymes for entire degradation pathway (Gerhardt et al.
2009). Hence, application of bacterial consortia consisting of several groups of degraders responsible for degradation of alkanes, cycloalkanes, or PAHs, seems to have a better potential in the rhizoremediation process (Kuiper et al. 2004). Interestingly, plant growth-promoting rhizobacteria (PGPR) that colonize plant roots may become key players in the remediation techniques. They not only stimulate plant growth, but also enhance pathogenic protection which in turn may further improve plant tolerance to abiotic stresses (Reed and Glick 2005; Lin et al. 2008; Robert et al. 2008; Wenzel 2008; Tang et al. 2010; Glick and Stearns 2011). In the recent years, endophytic bacteria have also gained much interest in the field of phytoremediation. This group of microorganisms resides inside plant tissues providing them with benefits in the similar manner as PGPR. However, endophytes do not compete with the surrounding microorganisms in soil which is often a disadvantage in the traditional bioaugmentation with rhizospheric microflora (Khan and Doty 2011; Reinhold-Hurek and Hurek 2011). Therefore, their role in conferring plant tolerance against xenobiotics seems to be crucial (Becerra-Castro et al. 2012).

The efficiency of rhizoremediation depends mostly on the establishment of a strong and sustained plant-microbe interaction (Nie et al. 2011). The first step in plant selection for remediation is identification of species that are able to grow and develop in oil-contaminated soil. In order to successfully remediate the polluted environment, plants should not only exhibit a significant tolerance towards certain pollutants, but they should also be characterized by an extensive root length and high biomass production (Huang et al. 2005). Many studies have concerned grasses (Poacae) and legumes (Leguminosae) as effective candidates for rhizoremediation (Mehmannavaz et al. 2002; Tesar et al. 2002; Gaskin et al. 2008; Muratova et al. 2008; Hong et al. 2011). Grasses are characterized by a deep root system which penetrates and subsequently aerates soil, thus creating a more extensive habitat for the colonizing petroleum degraders. On the other hand, legumes and their symbiotic relationship with $\mathrm{N}$-fixing rhizobia make them independent from limited nitrogen supply in oil-contaminated soil, which consequently increases the plants' chances for survival upon stress conditions (Muratova et al. 2008).

It is obvious that more plant species, which are able to produce high biomass in a contaminated soil, need to be identified for use in the rhizoremediation technology (Adam and Duncan 2002; Gaskin et al. 2008). For this reason, we investigated phytotoxicity of diesel oil 
towards four high biomass crop species: high erucic acid rapeseed (HEAR) and low erucic acid rapeseed (LEAR) (Brassica napus), Indian mustard (Brassica juncea), cultivar Malopolska, and alfalfa (Medicago sativa). Plant tolerance was evaluated with and without hydrocarbondegrading consortia in the contaminated soil. Using germination tests, including evaluation of the germination rate, root length, and biomass production we selected a plant-bacterial consortium pair which may be promising during a further rhizoremediation approach.

\section{Materials and Methods}

\subsection{Chemical Reagents}

Diesel oil was purchased from PKN Orlen, Poland. Germination plates (Phytotoxkit) that were used to assess phytotoxicity of diesel oil and to analyze the response of seedlings towards bioaugmentation, were purchased from Tigret Sp. z.o.o. (Warszawa, Poland). The control soil (according to OECD standards, ISO/DIS 11269-1) was also purchased from Tigret Sp. z.o.o. (Warszawa, Poland).

\subsection{Plants}

Four plant species were used in this study: HEAR and LEAR (B. napus), Indian mustard cultivar Malopolska (B. juncea), and alfalfa ( $M$. sativa). HEAR seeds were a kind gift from Dr Henryk Woś, Plant Breeding Strzelce, Group IHAR, Borowo, Poland, division. LEAR seeds were kindly given by RAPOOL Polska Sp. z o.o., Wagrowiec, Poland. Indian mustard seeds were obtained from "Centrala Nasienna" Sp. z o.o. Przedsiębiorstwo Hodowlano-Nasienne Stacja Hodowli Roślin, Poland, whereas alfalfa seeds were obtained from Barenbrug at Tarnowo Podgórne, Poland. Images of germinated plantlets were taken using a stereomicroscope (SteREO Lumar V12; Carl Zeiss) equipped with a digital camera (AxioCam MR05; Carl Zeiss).

\subsection{Microorganisms Applied for the Bioaugmentation Procedure}

Three microbial consortia (M10, R3, K52) used throughout this study were isolated previously from crude oilpolluted sites at the Carpathian Mountains, as described by Owsianiak et al. (2009). Each consortium exhibited different biodegradation potential towards diesel oil, as previously reported by Owsianiak et al. (2009). M10 consortium was a slow petroleum degrader and consists of Rhodoccocus equi, Betaproteobacterium, Enterobacter sp., Acinetobacter calcoaceticus, Comamonas sp., and Pseudomonas alcaligenes. R3 consortium exhibited a high biodegradation potential and consists of $P$. alcaligenes, Ochrobactrum intermedium, Klebsiella oxytoca, Sphingobacterium multivorum, Pseudomonas putida, Chryseobacterium sp., Stenotrophomonas maltophilia. K52 consortium consists of Pseudomonas stutzeri, Alcaligenes xylosoxidans, Sphingobacterium sp., Comamonadaceae bacterium, Citrobacter freundii, Sphingobacterium kitahiroshimense, and Pseudomonas sp. Bacteria were cultivated as described by Owsianiak et al. (2009).

\subsection{Germination Tests}

Germination tests were conducted in germination plates filled with 90-ml control soil and 35-ml distilled water. The oil-contaminated soil was spiked with diesel oil that was previously mixed with $2 \mathrm{~g}$ of sterile quartz. The diesel-contaminated soil used in the germination tests upon bioaugmentation was additionally inoculated with bacteria consortia at an appropriate volume corresponding to $10^{6}$ bacteria cells as per milliliter (Bashan 1986). Germination tests were carried out according to Banks and Schultz (2005) with some modifications. Seeds were surface-sterilized with $70 \%$ ethanol and rinsed with double distilled water. The first germination step was carried out in the dark at $23{ }^{\circ} \mathrm{C}$ for $48 \mathrm{~h}$. Afterwards, the germination plates were incubated in a growth chamber at $22^{\circ} \mathrm{C}$ for $96 \mathrm{~h}$, with a photoperiod of $12 / 12 \mathrm{~h}$, relative humidity $60 \%$, and photosynthetic photon flux density at $100 \mu \mathrm{mol}$ $\mathrm{m}^{-2} \mathrm{~s}^{-1}$. Germination tests were carried out in the following sets: (1) control soil (soil mixed with distilled water), (2) soil supplemented with diesel oil $\left(1,500,3,000,6,000,12,000,24,000 \mathrm{mg} \mathrm{kg}^{-1}\right.$ dry soil), (3) soil spiked with diesel oil at the selected concentrations and inoculated with bacteria consortia. Each test was prepared in triplicates.

In the end, the germination rate, root length, and dry biomass were assessed. Root length was measured using a ruler. In order to analyze dry biomass, roots and shoots were dried for $24 \mathrm{~h}$ at $65^{\circ} \mathrm{C}$. Collected data were used to calculate germination index (GI) and grade of growth inhibition (GGI) index: 
Germination index $(G I)=\frac{G s}{G c} \times \frac{L s}{L c} \times 100 \%$

where $G s$ and $G c$ are number of seeds germinated in the sample and control, respectively, whereas $L s$ and $L c$ are the radicle length in the sample and control, respectively;

Grade of growth inhibition index $(G G I)$

$$
=\frac{(D W c-D W s) \times 100 \%}{D W c}
$$

where $D W c$ and $D W s$ are dry mass of the control and sample, respectively.

\subsection{Statistical Analysis}

A one-way ANOVA was used to determine if there were significant differences in germination, root length, and dry biomass between replications. A univariate analysis of variance was also used to assess the statistical differences in plant development between seedlings growing on contaminated soil with and without bacteria consortia. Significance level was considered at $p<0.05$. All statistical analyses were performed using IBM SPSS Statistics 21 for Windows. If ANOVA showed significant effects, Tukey's test was used to determine differences among treatments.

\section{Results}

\subsection{Phytotoxicity of Diesel Oil towards Indian} Mustard, Alfalfa, HEAR, and LEAR Seedlings

All plant species demonstrated different germination patterns in diesel oil-spiked soil which is summarized in Fig. 1. For alfalfa seeds, the biggest increase of GI was observed at moderately contamination: 6,000 and $12,000 \mathrm{mg}$ diesel oil per kilogram dry soil (mg d.o. $\mathrm{kg}^{-1}$ d.s.), where it was 9 and $13 \%$ higher than control, respectively (Fig. 1). HEAR and LEAR displayed the highest increase of GI at 3,000 mg d.o. $\mathrm{kg}^{-1}$ d.s., which was 11 (HEAR) and $4 \%$ (LEAR) greater with reference to control (Fig. 1). The opposite tendency was noted for Indian mustard, where its GI declined along with the growing pollution in soil, apart from the test at $1,500 \mathrm{mg}$ d.o. $\mathrm{kg}^{-1}$ d.s. (Fig. 1).

The overall measurements of root length for all selected plant species demonstrated a decrease in conjugation

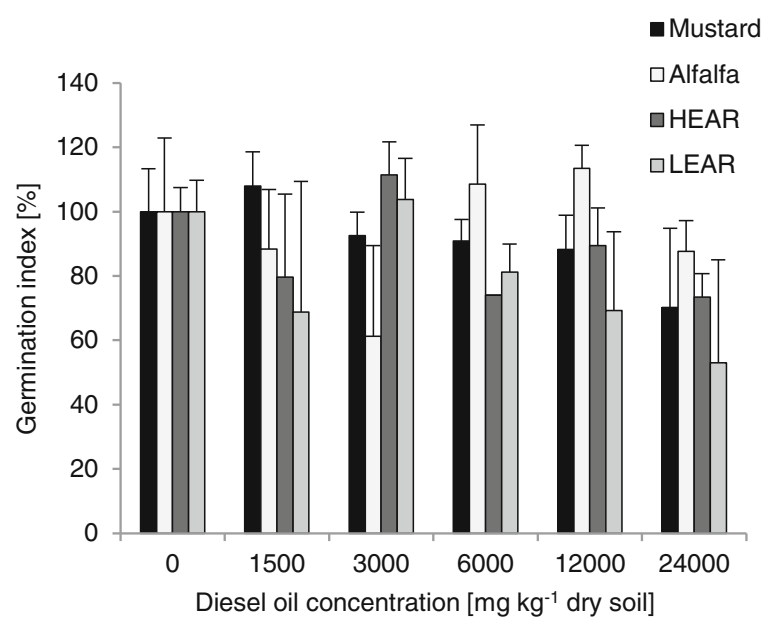

Fig. 1 Germination index of seedlings growing in diesel oilcontaminated soil. Mean values of three replicates $( \pm$ SD)

with the increasing contamination, besides a few exceptions (Fig. 2). Root length of alfalfa was respectively 7 and $3 \%$ greater at 6,000 and $12,000 \mathrm{mg}$ d.o. $\mathrm{kg}^{-1}$ d.s. treatments, when compared to control (Fig. 2). Additionally, we observed 10 and $7 \%$ increase in root elongation for HEAR and LEAR, respectively, at 3,000 mg d.o. $\mathrm{kg}^{-1}$ d.s., compared with the untreated seedlings (Fig. 2).

Biomass development is of key importance reflecting the photosynthetic capacity of plants and their adaptation to various stresses. Our results revealed varied biomass production responses among diesel oil treatments. Interestingly, as in the case of GI and root length measurements, the biggest increase (33\%) of

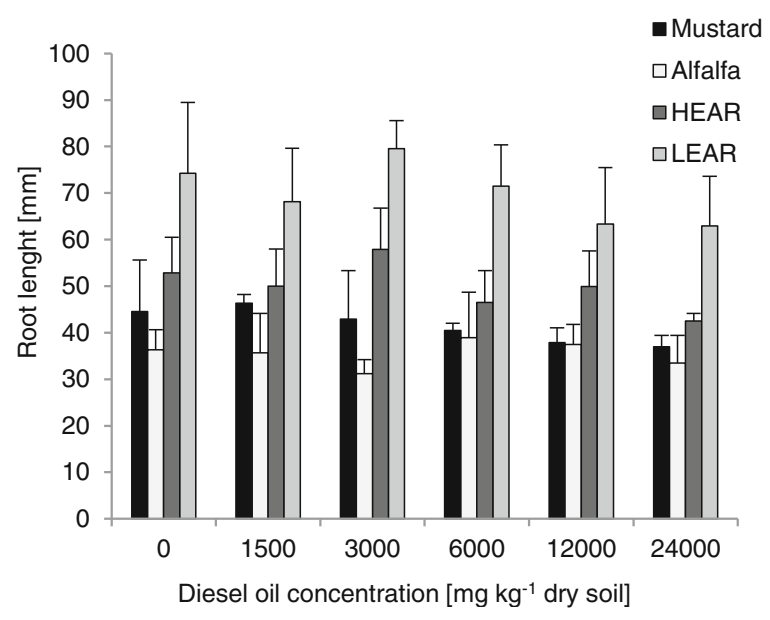

Fig. 2 Root length of seedlings growing in diesel oil-contaminated soil. Mean values of three replicates $( \pm \mathrm{SD})$ 
dry biomass for alfalfa was found at 6,000 mg d.o. $\mathrm{kg}^{-1}$ d.s (Fig. 3). It is also worth noting that HEAR biomass was higher in all assays (36, 22, 21, 42, $89 \%$ ) when compared to plants growing in uncontaminated soil (Fig. 3). Considering that the success of rhizoremediation strongly depends on a robust root system and photosynthetically active shoot, these organs have also been collected and analyzed separately. Although the shoot and root dry weight of Indian mustard was severely affected by presence of diesel oil in soil, other plant species showed positive response to the contaminant (Fig. 3). Alfalfa demonstrated bigger growth of root $(85 \%)$ and shoot $(3 \%)$ dry weight at the moderate pollution $\left(6,000 \mathrm{mg}\right.$ d.o. $\mathrm{kg}^{-1}$ d.s), when compared to seedlings germinating in soil with no fuel
(Fig. 3). Both HEAR and LEAR shoot dry biomass values reached a higher rate upon all pollutant concentrations when compared to control conditions. HEAR also presented bigger root dry weight $(43,20,36,62$, $142 \%)$ in all diesel treatments $(1,500 ; 3,000 ; 6,000$; 12,$000 ; 24,000 \mathrm{mg}$ d.o. $\mathrm{kg}^{-1}$ d.s.), attaining the highest increase at 24,000 mg d.o. $\mathrm{kg}^{-1}$ d.s. (Fig. 3).

The following data on dry weight were subsequently used to calculate the GGI (Fig. 4). In case where the dry biomass of treated plants was greater than control, the GGI has negative values. In both HEAR and LEAR diesel treatments, GGI values were negative, apart from the treatment with $12,000 \mathrm{mg}$ d.o. $\mathrm{kg}^{-1}$ d.s. The GGI for Indian mustard was positive at concentrations above $1,500 \mathrm{mg}$ d.o. $\mathrm{kg}^{-1}$ d.s., whereas alfalfa's growth
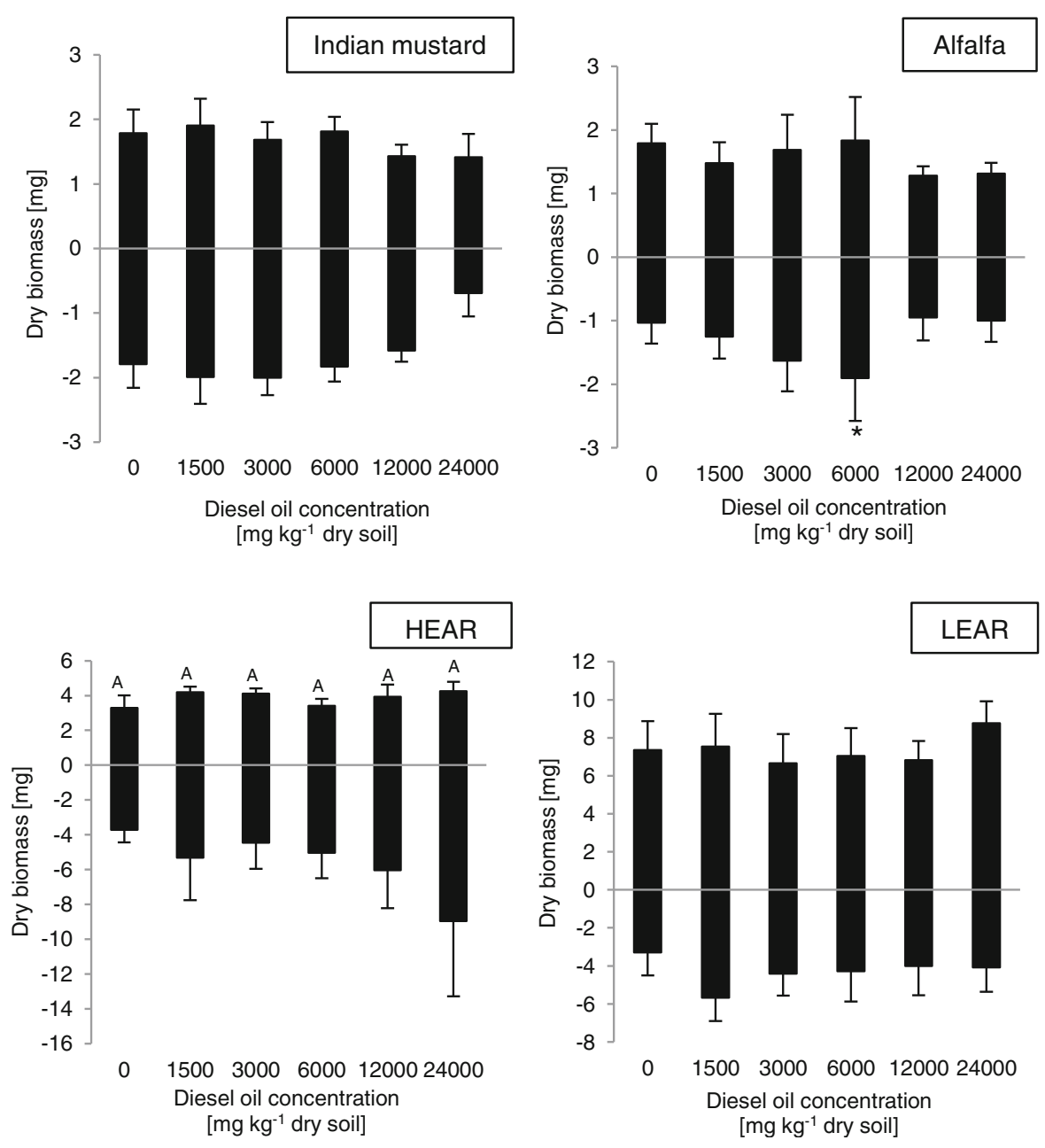

Fig. 3 Changes in the dry shoot (above $x$-axis) and root (below $x$-axis) weight of Indian mustard, alfalfa, HEAR, and LEAR growing in diesel oil-contaminated soil. Means of three replicates $( \pm \mathrm{SD})$, bars that are marked with $*$ are statistically significant at $p<0.05$ 


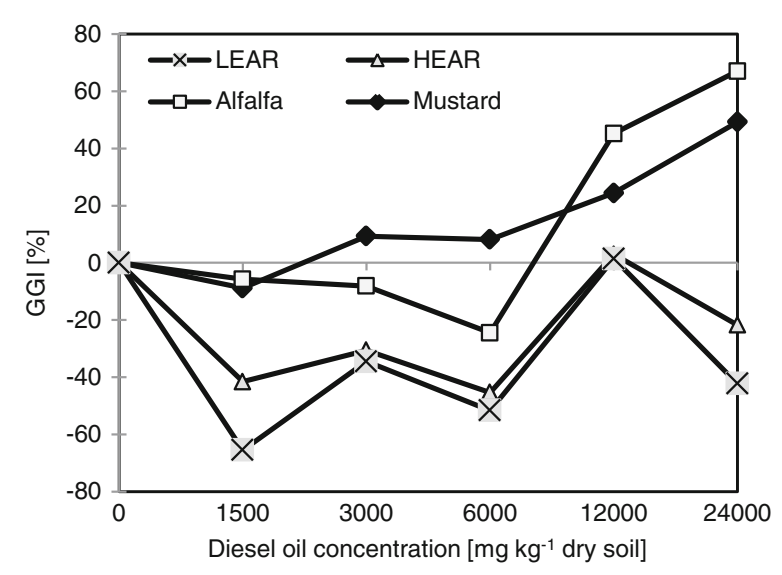

Fig. 4 Grade of growth inhibition of seedlings growing in diesel oil-contaminated soil

was only inhibited at higher soil pollution, corresponding to 12,000 and $24,000 \mathrm{mg}$ d.o. $\mathrm{kg}^{-1}$ d.s. (Fig. 4).

Since plant exposition to soil contamination may result in physiological alterations, we observed diesel oil phytotoxicity reflected by chlorosis and deformation of cotyledons. The most visible chlorotic symptoms were observed for Indian mustard. Although, alfalfa and both rapeseed varieties suffered from chlorosis at the greatest soil contamination, HEAR presented solely subtle chlorotic changes and indicated the highest level of tolerance towards pollutant which correlated with the GGI calculations. For visual representation of the morphological changes, the reader is referred to Fig. S1 in the Supplementary data (Online Resource 1).

\subsection{Germination and Growth upon Bioaugmentation}

The rhizoremediation approach aims at the application of the most efficient plant-microbe system, preferably suitable for certain geographical region. In order to determine the impact of petroleum-degrading consortia on plant tolerance towards diesel oil, the same life parameters of seedlings were assessed in the presence of bacteria that were previously isolated from the contaminated sites in the Polish Carpathian Mountains. The germination tests upon bioaugmentation were performed only at selected diesel oil concentrations (6,000 and 24,000 $\mathrm{mg}$ d.o. $\mathrm{kg}^{-1}$ d.s.).

As seen in Table 1, all seeds had different germination patterns depending on the consortium type they were enriched in. Undoubtedly, plants demonstrated improvements of GI in diesel oil-contaminated soil, when inoculated with M10 consortium (Table 1). GI of alfalfa was found to be 107,44 , and $24 \%$ greater upon M10 bioaugmentation across the treatments $(0 ; 6,000$; $24,000 \mathrm{mg}$ d.o. $\mathrm{kg}^{-1}$ d.s.) when compared to the noninoculated seeds (Table 1). A similar enhancing effect on germination rates was observed for Indian mustard and HEAR, where the GI was 23 and $20 \%$ bigger at $6,000 \mathrm{mg}$ d.o. $\mathrm{kg}^{-1}$ d.s., respectively, when compared to control values. No noticeable changes of GI were observed for seeds exposed to diesel fuel and R3 microorganisms, apart from the inoculated Indian mustard (22\% increase) grown upon 6,000 mg d.o. $\mathrm{kg}^{-1}$ d.s.. In the presence of K52 consortium, all plant species displayed a reduction of GI upon diesel oil (Table 1).

Seedling development in the diesel oil-contaminated soil similarly showed that the growth upon bioaugmentation varied depending on the applied bacterial consortium. In general, data from Table 2 reveals that plants inoculated with M10 consortium had longer roots upon 0 and 6,000 $\mathrm{mg}$ d.o. $\mathrm{kg}^{-1}$ d.s. conditions than seedlings enriched in R3 or K52 bacteria. Spiking with diesel oil at 24,000 mg d.o. $\mathrm{kg}^{-1}$ d.s. severely reduced root extension, particularly when K52 consortium was applied (Table 2). In detail, a notable increase of root length upon M10 inoculation was observed for HEAR at 6,000 and 24,000 mg d.o. $\mathrm{kg}^{-1}$ d.s., in comparison to the two remaining bioaugmentation types (Table 2). Furthermore, Indian mustard root elongation measurements also appeared to be greater upon M10 inoculation $(35,20$, and $13 \%)$ in all treatments $(0 ; 6,000 ; 24,000 \mathrm{mg}$ d.o. $\mathrm{kg}^{-1}$ d.s.). In addition, since alfalfa is recognized for its ability to form symbiotic relationships with soil bacteria, we found that seedlings enriched in petroleum degraders at no diesel treatment presented almost two times higher root length values than plants growing without consortia (Table 2). In the case of LEAR seedlings, their root length was slightly elongated only in the presence of M10 bacteria (15\%), but upon diesel pollution, all bioaugmentation types reduced the root length (Table 2).

Analysis of entire dry weight also showed diverse trends for biomass accumulation upon different bioaugmentation treatments (Table 3). Additionally, a separate analysis of root and shoot dry weight demonstrated that bioaugmentation changed the development of particular plant organs, thus influencing the entire plant's dry biomass (Fig. 5). Likewise, in case of root length a positive effect of bioaugmentation with M10 consortium on dry biomass production was noted for Indian mustard and HEAR at 6,000 mg d.o. $\mathrm{kg}^{-1}$ d.s. (Table 3). The 
Table 1 Germination index $( \pm$ SD) of plants growing in diesel oil-contaminated soil upon bioaugmentation with petroleum-degrading consortia (M10, R3, and K52)

\begin{tabular}{|c|c|c|c|c|}
\hline \multirow[t]{3}{*}{ Plant } & \multicolumn{3}{|c|}{ Germination index [\%] } & \multirow[t]{3}{*}{ Consortium } \\
\hline & \multicolumn{3}{|c|}{ Diesel oil concentration $\left[\mathrm{mg} \mathrm{kg}^{-1}\right.$ dry soil] } & \\
\hline & 0 & 6,000 & 24,000 & \\
\hline \multirow[t]{4}{*}{ Indian mustard } & $100 \pm 13$ & $91 \pm 7$ & $70 \pm 25$ & Control \\
\hline & $150 \pm 5$ & $123 \pm 5$ & $99 \pm 0$ & M10 \\
\hline & $91 \pm 14$ & $122 \pm 19$ & $91 \pm 18$ & R3 \\
\hline & $99 \pm 8$ & $53 \pm 15$ & $31 \pm 7$ & $\mathrm{~K} 52$ \\
\hline \multirow[t]{4}{*}{ Alfalfa } & $100 \pm 23$ & $109 \pm 18$ & $88 \pm 10$ & Control \\
\hline & $207 \pm 20$ & $144 \pm 7$ & $124 \pm 12$ & M10 \\
\hline & $205 \pm 29$ & $94 \pm 56$ & $90 \pm 11$ & $\mathrm{R} 3$ \\
\hline & $211 \pm 8$ & $44 \pm 19$ & $42 \pm 52$ & K52 \\
\hline \multirow[t]{4}{*}{ HEAR } & $100 \pm 7$ & $74 \pm 0$ & $73 \pm 8$ & Control \\
\hline & $135 \pm 17$ & $120 \pm 0$ & $75 \pm 42$ & M10 \\
\hline & $112 \pm 7$ & $85 \pm 28$ & $61 \pm 21$ & $\mathrm{R} 3$ \\
\hline & $114 \pm 7$ & $45 \pm 17$ & $42 \pm 0$ & K52 \\
\hline \multirow[t]{4}{*}{ LEAR } & $100 \pm 10$ & $81 \pm 9$ & $53 \pm 32$ & Control \\
\hline & $122 \pm 8$ & $65 \pm 0$ & $86 \pm 13$ & M10 \\
\hline & $78 \pm 10$ & $70 \pm 10$ & $40 \pm 0$ & R3 \\
\hline & $82 \pm 23$ & $14 \pm 14$ & $18 \pm 21$ & $\mathrm{~K} 52$ \\
\hline
\end{tabular}

comparison was performed with respect to the control non-inoculated seedlings. For Indian mustard, the most noticeable increase of root dry weight was obtained upon M10 inoculation at 0 and $6,000 \mathrm{mg}$ d.o. $\mathrm{kg}^{-1}$ d.s.

Table 2 Root length $( \pm \mathrm{SD})$ of seedlings growing in diesel oil-contaminated soil upon bioaugmentation with petroleum-degrading consortia (M10, R3, and K52)

\begin{tabular}{|c|c|c|c|c|}
\hline \multirow{2}{*}{$\begin{array}{l}\text { Plant } \\
\text { Indian mustard }\end{array}$} & \multicolumn{4}{|c|}{ Root length [mm] } \\
\hline & Control & M10 & R3 & K52 \\
\hline $0 \mathrm{mg} \mathrm{ON} \mathrm{kg}{ }^{-1}$ dry soil & $45 \pm 11 \mathrm{a}$ & $60 \pm 4 a$ & $42 \pm 4 \mathrm{a}$ & $45 \pm 11 \mathrm{a}$ \\
\hline $6,000 \mathrm{mg} \mathrm{ON} \mathrm{kg}^{-1}$ dry soil & $41 \pm 2 \mathrm{a}$ & $49 \pm 5 b$ & $57 \pm 5 b$ & $23 \pm 0,4 \mathrm{a}$ \\
\hline $24,000 \mathrm{mg} \mathrm{ON} \mathrm{kg}^{-1}$ dry soil & $37 \pm 2 b$ & $41 \pm 8 b$ & $41 \pm 8 b$ & $13 \pm 7 \mathrm{a}$ \\
\hline Alfalfa & Control & M10 & R3 & K52 \\
\hline $0 \mathrm{mg} \mathrm{ON} \mathrm{kg}^{-1}$ dry soil & $36 \pm 4 a$ & $60 \pm 2 b$ & $62 \pm 16 b$ & $68 \pm 7 b$ \\
\hline $6,000 \mathrm{mg} \mathrm{ON} \mathrm{kg}^{-1}$ dry soil & $39 \pm 10 \mathrm{a}$ & $41 \pm 20 \mathrm{a}$ & $35 \pm 0.6 \mathrm{a}$ & $15 \pm 2 \mathrm{a}$ \\
\hline $24,000 \mathrm{mg} \mathrm{ON} \mathrm{kg}^{-1}$ dry soil & $33 \pm 6 \mathrm{a}$ & $33 \pm 3 a$ & $33 \pm 4 a$ & $17 \pm 8 \mathrm{a}$ \\
\hline HEAR & Control & M10 & $\mathrm{R} 3$ & K52 \\
\hline $0 \mathrm{mg} \mathrm{ON} \mathrm{kg}^{-1}$ dry soil & $53 \pm 8 \mathrm{a}$ & $75 \pm 6 a$ & $59 \pm 13 a$ & $60 \pm 4 a$ \\
\hline $6,000 \mathrm{mg} \mathrm{ON} \mathrm{kg}^{-1}$ dry soil & $46 \pm 7 b$ & $60 \pm 2 b$ & $50 \pm 4 b$ & $25 \pm 4 \mathrm{a}$ \\
\hline $24,000 \mathrm{mg} \mathrm{ON} \mathrm{kg}^{-1}$ dry soil & $43 \pm 2 b c$ & $47 \pm 0,5 \mathrm{c}$ & $39 \pm 1 b$ & $21 \pm 1 \mathrm{a}$ \\
\hline LEAR & Control & M10 & $\mathrm{R} 3$ & K52 \\
\hline $0 \mathrm{mg} \mathrm{ON} \mathrm{kg}{ }^{-1}$ dry soil & $74 \pm 15 \mathrm{a}$ & $85 \pm 18 \mathrm{a}$ & $62 \pm 2 a$ & $66 \pm 4 a$ \\
\hline $6,000 \mathrm{mg} \mathrm{ON} \mathrm{kg}{ }^{-1}$ dry soil & $71 \pm 9 b$ & $64 \pm 4 b$ & $56 \pm 3 b$ & $12 \pm 0.05 \mathrm{a}$ \\
\hline $24,000 \mathrm{mg} \mathrm{ON} \mathrm{kg}^{-1}$ dry soil & $63 \pm 11 b$ & $63 \pm 15 b$ & $40 \pm 11 \mathrm{ab}$ & $16 \pm 3 a$ \\
\hline
\end{tabular}

Means that do not share letters differ at $p<0.05$ in the Tukey's test 
treatments, where it was four and two times higher, respectively, in relation to the non-bioaugmented plants (Fig. 5). HEAR shoot dry weight was increased upon bioaugmentation with M10 bacteria (40, 41, and $32 \%)$ in all treatments $\left(0 ; 6,000 ; 24,000 \mathrm{mg}\right.$ d.o. $\mathrm{kg}^{-1}$ d.s. bioaugmented) (Fig. 5). However, exposition to R3 consortium also promoted growth of HEAR particular organs: shoot $(29,62$, and $29 \%)$ in all tested conditions, as well as root (150 and $55 \%$ ) at 0 and 6,000 $\mathrm{mg}$ d.o. $\mathrm{kg}^{-1}$ d.s. bioaugmented (Fig. 5). Similar positive effect of R3 bioaugmentation was recorded for LEAR, where we observed a rising tendency of root dry biomass production $(58,2$, and $46 \%)$ across all tested diesel concentrations $\left(0 ; 6,000\right.$; and 24,000 $\mathrm{mg}$ d.o. $\mathrm{kg}^{-1}$ d.s.) (Table 3). Surprisingly, when LEAR was inoculated with K52 consortium, an extremely high increase of root dry weight (167 and $217 \%$ ) at 6,000 and $24,000 \mathrm{mg}$ d.o. $\mathrm{kg}^{-1}$ d.s. was observed, probably due to the development of many hairy roots (Fig. 5).

In the case of alfalfa, none of the applied consortia enhanced its dry biomass accumulation upon the presence of diesel oil (Table 3). On the other hand, the addition of microorganisms to alfalfa's rhizosphere caused a slight decline of its root and shoot dry biomass in comparison with the non-inoculated seedlings (Fig. 5).

Based on the seedling's dry weight, we calculated the grade of growth inhibition to summarize the influence of both diesel fuel and petroleum degraders on germination and development of tested crop species. It indicated that, in comparison to control, the growth of alfalfa was inhibited in the presence of all petroleum-degrading microorganisms and diesel oil in soil (Table 4). Similar observations were noticed for Indian mustard when exposed to R3 and K52 bacteria. However, inoculation with M10 consortium at 0 and 6,000 mg d.o. $\mathrm{kg}^{-1}$ d.s. had an advantageous influence on its dry biomass production (Table 4). The most promoting impact of bioaugmentation on seedling growth was obtained in case of rapeseed. When HEAR was inoculated with M10 bacteria its GGI was constantly negative upon all diesel oil treatments (Table 4), which reflects growth stimulation by M10 bacteria. The enrichment of HEAR in R3 microorganisms caused a severe decrease of GGI only at 0 and 6,000 mg d.o. $\mathrm{kg}^{-1}$ d.s. (Table 4). On the other hand, K52 microorganisms had the most promoting effect on LEAR growth in the polluted soil $(6,000$ and $24,000 \mathrm{mg}$ d.o. $\mathrm{kg}^{-1}$ d.s. ), where its GGI was 50 and

Table 3 Dry biomass of seedlings growing on diesel oil-contaminated soil upon bioaugmentation with petroleum degrading consortia (M10, R3, K52)

\begin{tabular}{|c|c|c|c|c|}
\hline \multirow{2}{*}{$\begin{array}{l}\text { Plant } \\
\text { Indian mustard }\end{array}$} & \multicolumn{4}{|l|}{ Dry biomass [mg] } \\
\hline & Control & M10 & R3 & K52 \\
\hline $0 \mathrm{mg} \mathrm{ON} \mathrm{kg}{ }^{-1}$ dry soil & $3.5 \pm 8 \mathrm{e}-04 \mathrm{a}$ & $9.0 \pm 2 \mathrm{e}-03 \mathrm{~b}$ & $2.8 \pm 6 \mathrm{e}-04 \mathrm{a}$ & $2.2 \pm 3 \mathrm{e}-04 \mathrm{a}$ \\
\hline $6,000 \mathrm{mg} \mathrm{ON} \mathrm{kg}{ }^{-1}$ dry soil & $3.3 \pm 6 \mathrm{e}-04 \mathrm{a}$ & $4.2 \pm 2 \mathrm{e}-03 \mathrm{a}$ & $2.1 \pm 3 \mathrm{e}-04 \mathrm{a}$ & $2.7 \pm 6 \mathrm{e}-04 \mathrm{a}$ \\
\hline $24,000 \mathrm{mg} \mathrm{ON} \mathrm{kg}{ }^{-1}$ dry soil & $2.0 \pm 3 \mathrm{e}-04 \mathrm{a}$ & $2.1 \pm 3 \mathrm{e}-04 \mathrm{a}$ & $1.7 \pm 4 \mathrm{e}-04 \mathrm{a}$ & $2.0 \pm 7 \mathrm{e}-05 \mathrm{a}$ \\
\hline Alfalfa & Control & M10 & $\mathrm{R} 3$ & K52 \\
\hline $0 \mathrm{mg} \mathrm{ON} \mathrm{kg}^{-1}$ dry soil & $2.8 \pm 2 \mathrm{e}-04 \mathrm{a}$ & $2.1 \pm 7 \mathrm{e}-04 \mathrm{a}$ & $2.3 \pm 3 \mathrm{e}-04 \mathrm{a}$ & $2.8 \pm 7 \mathrm{e}-05 \mathrm{a}$ \\
\hline $6,000 \mathrm{mg} \mathrm{ON} \mathrm{kg}^{-1}$ dry soil & $3.7 \pm 1 \mathrm{e}-03 \mathrm{a}$ & $2.2 \pm 3 \mathrm{e}-04 \mathrm{a}$ & $2.5 \pm 6 \mathrm{e}-04 \mathrm{a}$ & $2.6 \pm 2 \mathrm{e}-04 \mathrm{a}$ \\
\hline $24,000 \mathrm{mg} \mathrm{ON} \mathrm{kg}^{-1}$ dry soil & $2.3 \pm 5 \mathrm{e}-04 \mathrm{a}$ & $1.1 \pm 7 \mathrm{e}-04 \mathrm{a}$ & $1.7 \pm 1 \mathrm{e}-04 \mathrm{a}$ & $1.8 \pm 2 \mathrm{e}-04 \mathrm{a}$ \\
\hline HEAR & Control & M10 & R3 & K52 \\
\hline $0 \mathrm{mg} \mathrm{ON} \mathrm{kg}{ }^{-1}$ dry soil & $7.0 \pm 0.0 \mathrm{a}$ & $9.6 \pm 1 \mathrm{e}-03 \mathrm{a}$ & $13.4 \pm 7 \mathrm{e}-03 \mathrm{a}$ & $6.6 \pm 5 \mathrm{e}-04 \mathrm{a}$ \\
\hline $6,000 \mathrm{mg} \mathrm{ON} \mathrm{kg}^{-1}$ dry soil & $8.4 \pm 1 \mathrm{e}-03 \mathrm{a}$ & $9.0 \pm 2 \mathrm{e}-04 \mathrm{a}$ & $12.5 \pm 1 \mathrm{e}-03 \mathrm{a}$ & $8.0 \pm 1 \mathrm{e}-03 \mathrm{a}$ \\
\hline $24,000 \mathrm{mg} \mathrm{ON} \mathrm{kg}^{-1}$ dry soil & $13.2 \pm 4 \mathrm{e}-03 \mathrm{a}$ & $9.1 \pm 2 \mathrm{e}-03 \mathrm{a}$ & $8.1 \pm 2 \mathrm{e}-03 \mathrm{a}$ & $8.2 \pm 3 \mathrm{e}-03 \mathrm{a}$ \\
\hline LEAR & Control & M10 & R3 & K52 \\
\hline $0 \mathrm{mg} \mathrm{ON} \mathrm{kg}^{-1}$ dry soil & $10.6 \pm 2 \mathrm{e}-05 \mathrm{ab}$ & $10.5 \pm 1 \mathrm{e}-04 \mathrm{ab}$ & $15.2 \pm 1 \mathrm{e}-03 \mathrm{~b}$ & $7.8 \pm 2 \mathrm{e}-03 \mathrm{a}$ \\
\hline $6,000 \mathrm{mg} \mathrm{ON} \mathrm{kg}{ }^{-1}$ dry soil & $11.4 \pm 2 \mathrm{e}-03 \mathrm{a}$ & $14.1 \pm 2 \mathrm{e}-03 \mathrm{a}$ & $11.5 \pm 5 \mathrm{e}-05 \mathrm{a}$ & $16.6 \pm 9 \mathrm{e}-04 \mathrm{a}$ \\
\hline $24,000 \mathrm{mg} \mathrm{ON} \mathrm{kg}^{-1}$ dry soil & $12.8 \pm 3 e-03 b$ & $8.7 \pm 2 \mathrm{e}-04 \mathrm{a}$ & $13.8 \pm 7 \mathrm{e}-04 \mathrm{bc}$ & $17.1 \pm 2 \mathrm{e}-04 \mathrm{c}$ \\
\hline
\end{tabular}

Means that do not share letters differ at $p<0.05$ in the Tukey's test 

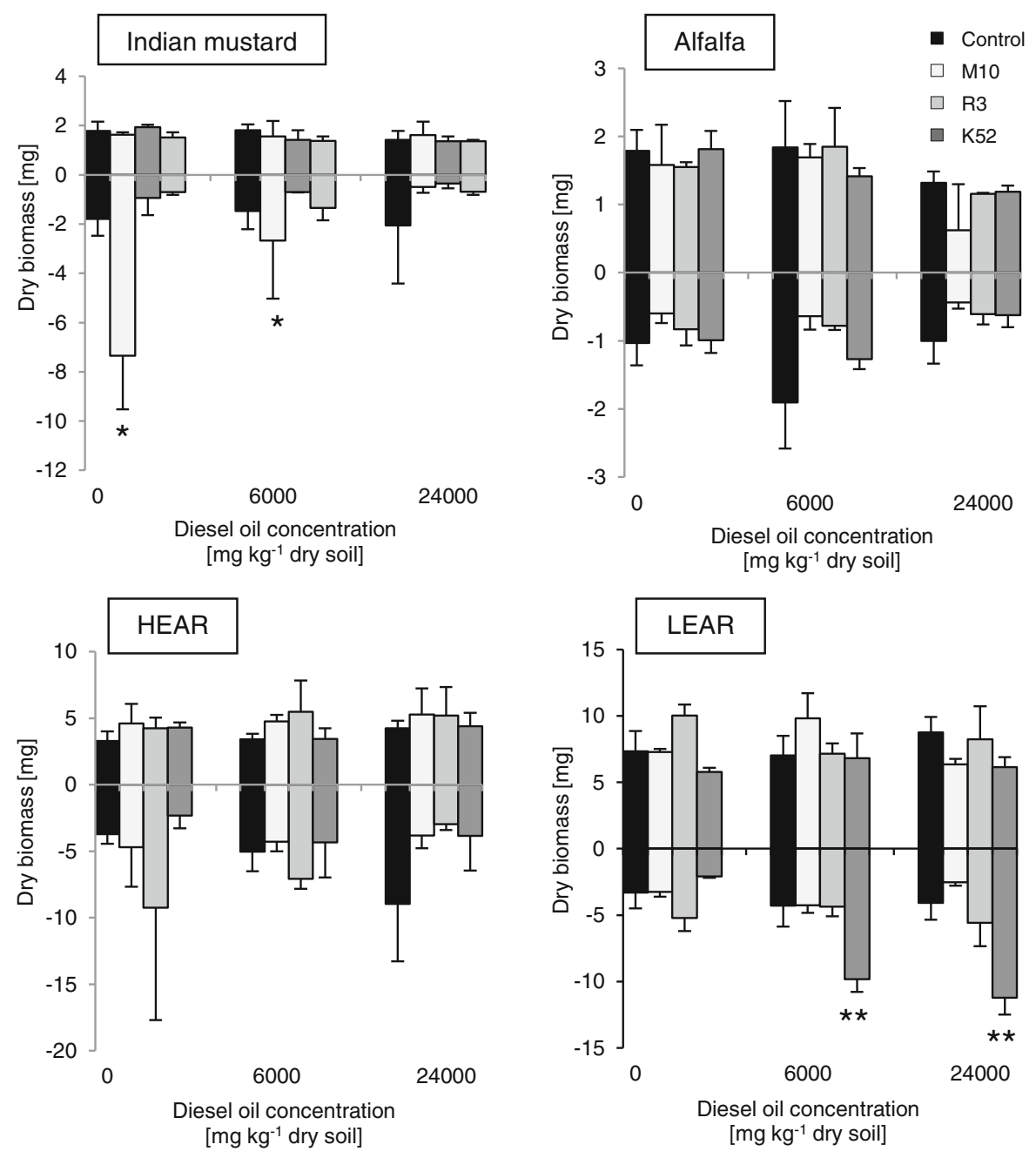

Fig. 5 Changes in the dry shoot (above $x$-axis) and root (below $x$ axis) weight of Indian mustard, alfalfa, HEAR, and LEAR growing in diesel oil-contaminated soil upon bioaugmentation with

$40 \%$ lower, respectively, when compared to control conditions (Table 4).

In order to determine the statistical significance between measurements of the presented growth parameters, the ANOVA test was used. Relevant differences of dry biomass production in diesel oil-contaminated soil and upon bioaugmentation are depicted in Figs. 3 and 5, as well as in Tables 2 and 3.

\section{Discussion}

The first and foremost issue in the rhizoremediation is a selection of plants that are able to grow and develop in

$\mathrm{M} 10, \mathrm{R} 3$, and $\mathrm{K} 52$ consortia. Means of three replicates $( \pm \mathrm{SD})$, bars that are marked with * are statistically significant at $p<0.05$ or $* *$ at $p<0.01$

oil-contaminated soil. A rising number of studies have demonstrated the application of Indian mustard and rapeseed in the phytoextraction of heavy metals, due to their capacity to accumulate high levels of $\mathrm{Zn}, \mathrm{Cu}, \mathrm{Cd}$, and $\mathrm{Se}$ (Kuiper et al. 2004; Ariyakanon and Winaipanich 2006; Grispen et al. 2006; Chauhan and Rai 2009). Similarly, Chekol and Vough (2001), Kaimi et al. (2007), Fan et al. (2008), and Marti et al. (2009) depicted alfalfa as a potential phytoremediator of organic contaminants, as well as its ability to germinate in petroleum-contaminated soil. Plants' tolerance towards a particular soil contamination is crucial in the further screening of suitable bacteria for rhizoremediation process (Muratova et al. 2008; Bona et al. 2011). Once a successful plant candidate is well 
Table 4 Grade of growth inhibition of seedlings growing on diesel oil-contaminated soil upon bioaugmentation with petroleum degrading consortia (M10, R3, and $\mathrm{K} 52$ )

\begin{tabular}{|c|c|c|c|c|}
\hline \multirow[t]{3}{*}{ Plant } & \multicolumn{3}{|c|}{ GGI [\%] } & \multirow[t]{3}{*}{ Consortium } \\
\hline & \multicolumn{3}{|c|}{ Diesel oil concentration $\left[\mathrm{mg} \mathrm{kg}^{-1}\right.$ dry soil $]$} & \\
\hline & 0 & 6,000 & 24,000 & \\
\hline \multirow[t]{4}{*}{ Indian mustard } & 0 & 8 & 45 & Control \\
\hline & -151 & -18 & 41 & M10 \\
\hline & 20 & 41 & 52 & $\mathrm{R} 3$ \\
\hline & 38 & 24 & 43 & K52 \\
\hline \multirow[t]{4}{*}{ Alfalfa } & 0 & -33 & 18 & Control \\
\hline & 23 & 19 & 63 & M10 \\
\hline & 16 & 9 & 38 & R3 \\
\hline & 0,6 & 5 & 36 & K52 \\
\hline \multirow[t]{4}{*}{ HEAR } & 0 & -21 & -89 & Control \\
\hline & -38 & -29 & -30 & M10 \\
\hline & -93 & -79 & -17 & R3 \\
\hline & 6 & -11 & -18 & K52 \\
\hline \multirow[t]{4}{*}{ LEAR } & 0 & -6 & -21 & Control \\
\hline & 1 & -32 & 18 & M10 \\
\hline & -43 & -8 & -30 & R3 \\
\hline & 26 & -56 & -61 & K52 \\
\hline
\end{tabular}

established in a polluted environment, it results in an enhancement of the contaminant breakdown by microorganisms that are supplied by plants with essential nutrients in the form of root exudates (Adam and Duncan 2002; Hong et al. 2011). Our experiment was aimed at screening plant tolerance towards diesel oil upon bioaugmentation and showed different response patterns, depending on plant species, concentration of diesel fuel, as well as the applied bacterial consortium.

\subsection{Diesel Concentration-Dependent Tolerance of Crop Plants}

Germination is an extremely important stage in the plant's development, being very sensitive to any kind of contamination. Exposition of seeds to hydrocarboncontaminated soil may result in poor germination, which can be followed by a retarded seedling growth (Reynoso-Cuevas et al. 2008). We observed that the germination rate was associated with the root length of every selected plant species. For Indian mustard, both GI and root length was decreasing along with the growing diesel oil concentration in soil. Peng et al. (2009) assumed that soil polluted by petroleum hydrocarbons may have an adverse effect for plant development reflected in the reduction of germination, inhibition of photosynthesis, and nutrient assimilation, in consequence causing the shortening of plant organs. Furthermore, Kamath et al. (2004) reported on a correlation between soil pollution degree and its subsequent harmful effect on plant germination and growth. Apart from that, it is commonly known that the rate of diesel oil phytotoxicity increases along with the growing content of volatile hydrocarbons, which are particularly harmful due to their ability to penetrate cell membranes (Adam and Duncan 2002). One of the mechanisms suggested by Sharifi et al. (2007), explaining the reduction of germination rate, is the fact that oily compounds can create a sort of biofilm and cover the entire seed surface, thus altering physiological processes inside the seed. In contrast, at moderate soil contamination alfalfa $\left(6,000 \mathrm{mg}\right.$ d.o. $\mathrm{kg}^{-1}$ d.s. $)$, as well as HEAR and LEAR (3,000 mg d.o. $\mathrm{kg}^{-1}$ d.s.) exhibited an increase of both GI and root length, with reference to control. Similar observations were obtained by Sharifi et al. (2007) who demonstrated an 84 and $43 \%$ increment of germination rate for Triticum sativa and Medicago truncatula, even at 25-g spent oil per kilogram soil. Moreover, Muratova et al. (2008) reported also an increase of germination for crop plants 
by $10-27 \%$, growing in an oil sludge-contaminated soil. The most likely explanation of these findings would be the fact that at low concentrations, petroleum hydrocarbons act as phytohormones and play a similar role to auxins (Reed and Glick 2005). However, at a greater concentration, hydrocarbons can obviously reduce plant growth and decrease carbon fixation (Reed and Glick 2005).

In order to further understand the effect of diesel fuel phytotoxicity on seedlings, we studied growth and biomass production of the tested plants. Our results revealed a loss of biomass for Indian mustard across the rising diesel fuel concentration in soil. This observation was correlating with the measurements of GI and root length. Taken together, these results would further confirm the hypothesis of Reynoso-Cuevas et al. (2008) regarding interconnection among the decreased germination rate and subsequent poor growth in the hydrocarbon-polluted soil. Apparently, in conjugation with an increasing soil contamination, a high abiotic stress during germination stage altered the physiology and early metabolism of Indian mustard, resulting in a biomass reduction which might reflect its poor tolerance towards diesel pollution. Although the greatest biomass production among all tested species was observed for LEAR, its fresh biomass, as in the case of Indian mustard, was declining along with the increasing contamination level. Interestingly, the opposite tendency was recorded for HEAR. One of the major differences between LEAR and HEAR is the content of erucic acid and glucosinolates. In HEAR, the erucic acid ranges about $40-50 \%$ and in LEAR, it does not exceed $2 \%$ (Nath et al. 2009; Iniguez-Luy and Federico 2011). Perhaps the metabolism of fatty acids in different rapeseed varieties could have a substantial impact on its response to petroleum hydrocarbons and lead to an enhanced or reduced adaptation to a contaminated environment. However, Ogbo (2009) suggested that phytotoxic impact of diesel oil might not only be due to its concentration, but also due to the hydrocarbon content, as well as soil type and properties. Furthermore, the disruptive effect of xenobiotics varies greatly among plants and some species may develop a specific resistance towards certain pollutants (Ogbo 2009). It is in agreement with our findings that alfalfa exhibited higher fresh biomass (data not shown), as well as total dry biomass at moderate diesel concentration (3,000 and 6,000 $\mathrm{mg}$ d.o. $\mathrm{kg}^{-1}$ d.s.), in comparison to control. More importantly, these results could be further associated with the hypothesis of stimulating effect of diesel oil and indicate the plant's tolerance towards lower soil contaminations (Reed and Glick 2005; Muratova et al. 2008). With this outcome the presented study would imply potential application of alfalfa in the remediation of moderately polluted sites. Additionally, considering a robust root development at 6,000 mg d.o. $\mathrm{kg}^{-1}$ d.s. alfalfa's rhizosphere could provide ideal dwelling conditions for the petroleumdegrading microbes and subsequently result in an enhanced hydrocarbon decomposition in soil (Fan et al. 2008). Nevertheless, the analysis of biomass accumulation clearly indicated that in comparison with Indian mustard and alfalfa, HEAR and LEAR presented a higher level of tolerance towards diesel fuel. Moreover, HEAR also displayed an increase of root biomass, reaching the greatest weight in the most contaminated soil, which may indicate its potential for remediation of petroleumcontaminated soils. This observation is particularly essential, since the main criterion for establishing a vegetation cover in clean-up technologies is an adequately high root biomass production, which can sufficiently supply plants with water and nutrients (Kamath et al. 2004; Reynoso-Cuevas et al. 2008; Gerhardt et al. 2009).

\subsection{The Role of Bioaugmentation in Response to Diesel Oil}

A positive effect of microorganisms on plants exposed to soil contaminated with petroleum derivatives has been described recently (Cameotra and Makkar 2010; Hong et al. 2011), however, application of petroleum degraders in the rhizoremediation process is not trivial. We would like to emphasize that in our experiments, we used consortia previously isolated from crude oilcontaminated sites in the Polish Carpathian Mountains (Owsianiak et al. 2009), instead of indigenous populations inhabiting the rhizosphere of certain plants. This makes the presented study a novel approach, since the number of investigations sharing a similar idea is limited (Lin et al. 2008; Juhanson et al. 2009). We showed that all plant species demonstrated the greatest germination rate upon bioaugmentation with M10 consortium. However, when exposed to diesel oil and K52 bacteria, the GI was undoubtedly diminished. Regarding R3 microorganisms, a notable influence on the germination was observed only in a few cases: Indian mustard (6,000 mg d.o. $\mathrm{kg}^{-1}$ d.s.), alfalfa (0 mg d.o. 
$\mathrm{kg}^{-1}$ d.s.), and HEAR (0 and 6,000 $\mathrm{mg}$ d.o. $\mathrm{kg}^{-1}$ d.s.). Furthermore, GI of most plants upon M10 inoculation and exposition to contaminated soil was significantly higher, when compared to the non-inoculated treatment with diesel. Perhaps among all tested consortia M10 bacteria are the most efficient seed protectors against toxic impact of diesel oil. This idea is supported by Nelson (2004), who reported that during seed germination bacterial community proliferation may be stimulated by seed exudates in the spermosphere (analog to rhizosphere), with their exudation rate strongly depending on the type of microorganisms. An increase of GI for all plant species exposed to M10 consortium and pollution was associated with their enhanced root growth. This correlates with the suggested connection between germination rate and subsequent plant growth (Reynoso-Cuevas et al. 2008). Again, the most positive effect on biomass production was credited to the M10 bacteria. Such an advantageous influence on plant development under contamination might be additionally explained by composition of M10 consortium. It consisted of Enterobacter, Pseudomonas, Rhodococcus, and Acinetobacter strains that are known for their plant growth-promoting features (Saharan and Nehra 2011), as well as an excellent ability to degrade hydrocarbons (Sorkhoh et al. 1990; Espeche et al. 1994; Kuiper et al. 2004; Chang et al. 2011; Liu et al. 2011; Tyagi et al. 2011). As mentioned above, the root length of HEAR and Indian mustard inoculated with M10 consortium upon diesel oil treatments was also higher than in the case of the non-inoculated plants and significantly greater than those enriched in K52 bacteria. It seemed to us that along with the application of inoculum, a decline of GI and root length of plants exposed to the contaminated soil was compensated by positive plant-bacteria interactions (Huang et al. 2004). Such a phenomenon would be the first step for establishment of a successful rhizoremediation microbial consortium, which could promote maintenance of a stable vegetation cover in a diesel oil-contaminated soil. The impact of bioaugmentation on germination and root growth are of great importance and these bacteria, which present destructive influence, should not be further applied in rhizoremediation (Gerhardt et al. 2009). Another issue undoubtedly having an impact on the success of rhizoremediation strategy is the microbial ability to colonize growing roots. This can be achieved by using a suitable microbe-plant pair, as in the case of e.g., naphthalene degraders in association with grasses. In this case, bacteria protect seeds from the harmful effect of contaminant, whereas grass roots provide bacteria with an extensive colonization surface (Gerhardt et al. 2009). A great number of publications recognized leguminous plants, particularly alfalfa, as a suitable candidate for rhizoremediation process. Due to its high resistance towards aromatic compounds, as well as a widely branched root system, it can create an ideal condition for microbial proliferation (Kirk et al. 2005; Fan et al. 2008; Marti et al. 2009; Muratova et al. 2009). Surprisingly, this was not in agreement with our findings which showed a significant increase of alfalfa root length solely in the uncontaminated soil. It appeared to us that probably during diesel oil degradation in soil, some of the residual or incompletely metabolized compounds contributed to the acute effects in alfalfa and affected its growth (Lambert et al. 1995; Salanitro et al. 1997; Van Hamme et al. 2003). However, this phenomenon raises a number of questions and an additional study of this topic is therefore recommended. Future work might include qualitative and quantitative analysis of microbial metabolites during diesel oil decomposition and their impact on alfalfa's development. A plausible explanation for this issue could be the fact that some products of bacterial origin, e.g., biosurfactants are known to increase the hydrocarbon availability through their solubilization. Similar conclusions are reported by Millioli et al. (2009), who demonstrated total germination inhibition of Lactuca sativa in the soil that was contaminated with crude oil $\left(50 \mathrm{mg} \mathrm{g}^{-1}\right)$ and supplemented with rhamnolipids $\left(8 \mathrm{mg} \mathrm{g}^{-1}\right)$. Comparable results were described by Marecik et al. (2012). These authors also observed a significant drop of dry biomass among inoculated plants exposed to soil spiked with diesel oil and supplemented with rhamnolipids, in comparison with seedlings growing in soil solely supplemented by rhamnolipids. Hence, we assumed that some of the applied consortia may possess the ability to produce biosurfactants which can increase the bioavailability of diesel oil derivatives, resulting in a higher phytotoxicity towards plants.

Despite the fact that ANOVA test yielded few statistically significant differences throughout this experiment (Figs. 3 and 5, Tables 2 and 3), we are convinced that diesel oil-contamination had an unquestionable effect on plant growth. Probably the effect of pollution on germination and root elongation was too small to be detected by the applied statistical test. In order to overcome this problem, future analysis should involve more replicates than our current experiment. Hence, we 
believe that by increasing either the number of seeds in the test or the precision of measurements, we would obtain a higher statistical power and less bias among results. Moreover, it has to be emphasized that the decision to use a $p$ value of 0.05 to determine significance was arbitrary but widely accepted. Ideally, we should judge the findings of our study on that level, but since we observed e.g., repeatedly declining tendency of Indian mustard growth, we would like to stress its low tolerance towards diesel pollution. On the other hand, since repetitive increase of alfalfa growth at 6,000 mg d.o. $\mathrm{kg}^{-1}$ d.s. has not been found anywhere else, it clearly indicates its stimulation by diesel oil at medium contamination. Moreover, we determined HEAR as the most tolerant species towards diesel oil. This assessment was not only based on the collected growth parameters, but also on visual changes in morphology and their comparison to other plants (Online Resources 1). In addition, we noted the most positive impact of M10 consortium on HEAR root length and biomass accumulation, thus we do consider HEAR and M10 bacteria as a suitable plant-microbe pair and their possible application in rhizoremediation. Taken all together, statistical significance is important, however, to guide us in the interpretation of the study's results. In further steps, we will investigate a long-term effect of bioaugmentation with M10 consortium.

\section{Conclusions}

All screened plants presented different germination and growth patterns, depending on the diesel oil concentration in soil which indicates that tolerance towards petroleum hydrocarbons is species specific. This investigation showed that the rate of diesel fueltolerance was increasing in the following order: Indian mustard $<$ alfalfa $<$ HEAR $<$ LEAR. Bioaugmentation with three different diesel-degrading consortia depicted M10 bacteria in combination with HEAR as the most promising plant-microbe interaction for the rhizoremediation. Nevertheless, it is evident that selection of a tolerant plant and its growth-promoting bacteria is not enough to ensure an optimal rhizoremediation. We therefore point out that described experiment was the first step for establishing an efficient rhizoremediation approach and more research is desirable in order to test the feasibility of the presented strategy. Plants' biochemical response to diesel contamination and microbial inoculation, as well as transcriptional level of several genes involved in the plant antioxidative and detoxification system will be in focus. Obviously, microbial activities in soil and diesel oil removal are key issues that will be also estimated, to verify our hypothesis on the potential rhizoremediation system that should efficiently clean up the polluted soil. On the basis of the promising findings presented in this paper, further work on the remaining issues will be continued and presented in more details in the future.

Acknowledgments This work has been supported financially by the Foundation for Polish Science, the HOMING PLUS Programme, co-financed from European Union structural funds under Action 1.2 "Strengthening the human resources potential of science" of the Innovative Economy Operational Programme 20072013. Ł. Chrzanowski is an official collaborator in this project. The authors thank all the co-workers at the Department of Biochemistry, Adam Mickiewicz University for their professional help in the project, as well as involved students: Elisa Pena Jimenez and Piotr Kaczmarek.

Open Access This article is distributed under the terms of the Creative Commons Attribution License which permits any use, distribution, and reproduction in any medium, provided the original author(s) and the source are credited.

\section{References}

Adam, G., \& Duncan, H. (2002). Influence of diesel fuel on seed germination. Environmental Pollution, 120, 363-370. doi:10.1016/S0269-7491(02)00119-7.

Ahammed, G. J., Wang, M. M., Zhou, Y. H., Xia, X. J., Mao, W. H., Shi, K., et al. (2012). The growth, photosynthesis and antioxidant defense responses of five vegetable crops to phenanthrene stress. Ecotoxicology and Environmental Safety, 80, 132-139. doi:10.1016/j.ecoenv.2012.02.015.

Alkio, M., Tabuchi, T. M., Wang, X., \& Colon-Carmona, A. (2005). Stress responses to polycyclic aromatic hydrocarbons in Arabidopsis include growth inhibition and hypersensitive response-like symptoms. Journal of Experimental Botany, 56(421), 2983-2994. doi:10.1093/jxb/eri295.

Ariyakanon, N., \& Winaipanich, B. (2006). Phytoremediation of copper contaminated soil by Brassica juncea (L.) and Bidens alba (L.) DC. var. radiata. Journal of Scientific Research Chulalongkorn University, 31(1), 49-56.

Banks, M., \& Schultz, K. (2005). Comparison of plants for germination toxicity tests in petroleum-contaminated soils. Water, Air, and Soil Pollution, 167(1-4), 211-219. doi:10. 1007/s11270-005-8553-4.

Bashan, Y. (1986). Significance of timing and level of inoculation with rhizosphere bacteria on wheat plants. Soil Biology and Biochemistry, 18(3), 297-301. doi:10.1016/00380717(86)90064-7. 
Becerra-Castro, C., Monterroso, C., Prieto-Fernandez, A., Rodriguez-Lamas, L., Loureiro-Vinas, M., Acea, M. J., et al. (2012). Pseudometallophytes colonising $\mathrm{Pb} / \mathrm{Zn}$ mine tailings: a description of the plant-microorganism-rhizosphere soil system and isolation of metal-tolerant bacteria. Journal Hazard Material, 217, 350-359. doi:10.1016/j.jhazmat.2012.03.039.

Böltner, D., Godoy, P., Munoz-Rojas, J., Duque, E., MorenoMorillas, S., Sanchez, L., et al. (2008). Rhizoremediation of lindane by root-colonizing Sphingomonas. Microbiology and Biotechnology, 1(1), 87-93. doi:10.1111/j.1751-7915. 2007.00004.x.

Bona, C., Rezende, I., Santos, G., \& Souza, L. (2011). Effect of soil contaminated by diesel oil on the germination of seeds and the growth of Schinus terebinthifoilus. Brazilian Archives of Biology and Technology, 54(6), 1379-1387. doi:10.1590/S1516-89132011000600025.

Cameotra, S. S., \& Makkar, R. S. (2010). Biosurfactantenhanced bioremediation of hydrophobic pollutants. Pure and Applied Chemistry, 82(1), 97-116. doi:10.1351/paccon-09-02-10.

Chang, L. K., Ibrahim, D., \& Omar, I. C. (2011). A laboratory scale bioremediation of Tapis crude oil contaminated soil by bioaugmentation of Acinetobacter baumannii T30C. African Journal of Microbiology Research, 5(18), 2609-2615. doi:10.5897/AJMR11.185.

Chauhan, J. S., \& Rai, J. P. N. (2009). Phytoextraction of soil cadmium and zinc by microbes-inoculated Indian mustard (Brassica juncea). Journal of Plant Interactions, 4(4), 279287. doi:10.1080/17429140903243427.

Chekol, T., \& Vough, L. (2001). A study of the use of alfalfa (Medicago sativa L.) for phytoremediation of organic contaminants in soil. Remediation Journal, 11(4), 89-101. doi:10.1002/rem.1017.

Espeche, M. E., Maccormack, W. P., \& Fraile, E. R. (1994). Factors affecting growth of an n-hexadecane degrader Acinetobacter species isolated from a highly polluted urban river. International Biodeterioration \& Biodegradation, 33(2), 187-196. doi:10.1016/0964-8305(94)90037-x.

Fan, S., Li, P., Gong, Z., Ren, W., \& He, N. (2008). Promotion of pyrene degradation in rhizosphere of alfalfa (Medicago sativa L.). Chemosphere, 71(8), 1593-1598. doi:10.1016/ j.chemosphere.2007.10.068.

Gaskin, S., Soole, K., \& Bentham, R. (2008). Screening of Australian native grasses for rhizoremediation of aliphatic hydrocarboncontaminated soil. International Journal of Phytoremediation, 10(5), 378-389. doi:10.1080/15226510802100465.

Gerhardt, K. E., Huang, X.-D., Glick, B. R., \& Greenberg, B. M. (2009). Phytoremediation and rhizoremediation of organic soil contaminants: potential and challenges. Plant Science, 176(1), 20-30. doi:10.1016/j.plantsci.2008.09.014.

Glick, B. R., \& Stearns, J. C. (2011). Making phytoremediation work better: maximizing a plant's growth potential in the midst of adversity. International Journal of Phytoremediation, 13(sup1), 4-16. doi:10.1080/15226514.2011.568533.

Grispen, V. M. J., Nelissen, H. J. M., \& Verkleij, J. A. C. (2006). Phytoextraction with Brassica napus L.: a tool for sustainable management of heavy metal contaminated soils. Environmental Pollution, 144(1), 77-83. doi:10.1016/j.envpol. 2006.01.007.

Hong, S. H., Ryu, H., Kim, J., \& Cho, K. S. (2011). Rhizoremediation of diesel-contaminated soil using the plant growth-promoting rhizobacterium Gordonia sp. S2RP-17. Biodegradation, 22(3), 593-601. doi:10.1007/s10532-0109432-2.

Huang, X. D., El-Alawi, Y., Penrose, D. M., Glick, B. R., \& Greenberg, B. M. (2004). A multi-process phytoremediation system for removal of polycyclic aromatic hydrocarbons from contaminated soils. Environmental Pollution, 130(3), 465-476. doi:10.1016/j.envpol.2003.09.031.

Huang, X.-D., El-Alawi, Y., Gurska, J., Glick, B. R., \& Greenberg, B. M. (2005). A multi-process phytoremediation system for decontamination of persistent total petroleum hydrocarbons (TPHs) from soils. Microchemical Journal, 81(1), 139-147. doi:10.1016/j.microc.2005.01.009.

Iniguez-Luy, F. L., \& Federico, M. L. (2011). The genetics of Brassica napus. In R. Schmidt \& I. Bancroft (Eds.), Genetics and genomics of the Brassicaceae (Vol. 9, pp. 291-322). New York: Springer.

Juhanson, J., Truu, J., Heinaru, E., \& Heinaru, A. (2009). Survival and catabolic performance of introduced Pseudomonas strains during phytoremediation and bioaugmentation field experiment. FEMS Microbial Ecology, 70, 446-455. doi:10.1111/j.1574-6941.2009.00754.x.

Kaimi, E., Mukaidani, T., \& Tamaki, M. (2007). Screening of twelve plant species for phytoremediation of petroleum hydrocarboncontaminated soil. Plant Production Science, 10(2), 211-218. doi:10.1626/pps.10.211.

Kamath, R., Rentz, J. A., Schnoor, J. L., \& Alvarez, P. J. J. (2004). Phytoremediation of hydrocarbon-contaminated soils: principles and applications. Petroleum Biotechnology: Developments and Perspectives, 151, 447-478.

Khan, Z., \& Doty, S. (2011). Endophyte-assisted phytoremediation. In Current topics in plant biology (12th ed., pp. 97-105).

Kirk, J. L., Klironomos, J. N., Lee, H., \& Trevors, J. T. (2005). The effects of perennial ryegrass and alfalfa on microbial abundance and diversity in petroleum contaminated soil. Environmental Pollution, 133(3), 455-465. doi:10.1016/j. envpol.2004.06.002.

Kuiper, I., Lagendijk, E., Bloemberg, G., \& Lugtenberg, B. (2004). Rhizoremediation - a beneficial plant-microbe interaction. Molecular Plant Microbe Interactions, 17(1), 6-15. doi:10.1094/MPMI.2004.17.1.6.

Lambert, M., Kremer, S., \& Anke, H. (1995). Antimicrobial, phytotoxic, nematicidal, cytotoxic and mutagenic activities of 1-hydroxypirene, the initial metabolite in pyrene metabolism by the basidiomycete Crinipellis stipitaria. Bulletin Environmental Contamination Toxicology, 55, 251-257. doi:10.1007/BF00203017.

Lin, X., Li, X., Li, P., Li, F., Zhang, L., \& Zhou, Q. (2008). Evaluation of plant-microorganism synergy for the remediation of diesel fuel contaminated soil. Bulletin of Environmental Contaminatin Toxicology, 81(1), 19-24. doi:10. 1007/s00128-008-9438-1.

Liste, H., \& Felgentreu, D. (2006). Crop growth, culturable bacteria, and degradation of petrol hydrocarbons (PHCs) in a long-term contaminated field soil. Applied Soil Ecology, 31(1-2), 43-52. doi:10.1016/j.apsoil.2005.04.006.

Liu, P. W. G., Chang, T. C., Whang, L. M., Kao, C. H., Pan, P. T., \& Cheng, S. S. (2011). Bioremediation of petroleum hydrocarbon contaminated soil: effects of strategies and microbial community shift. International Biodeterioration \& 
Biodegradation, 65(8), 1119-1127. doi:10.1016/j.ibiod. 2011.09.002.

Marecik, R., Wojtera-Kwiczor, J., Lawniczak, L., Cyplik, P., Szulc, A., Piotrowska-Cyplik, A., et al. (2012). Rhamnolipids increase the phytotoxicity of diesel oil towards four common plant species in a terrestrial environment. Water, Air, and Soil Pollution, 223(7), 4275-4282. doi:10. 1007/s11270-012-1190-9.

Marti, M. C., Camejo, D., Fernandez-Garcia, N., RellanAlvarez, R., Marques, S., Sevilla, F., et al. (2009). Effect of oil refinery sludges on the growth and antioxidant system of alfalfa plants. Journal of Hazardous Material, 171(1-3), 879-885. doi:10.1016/j.jhazmat.2009.06.083.

Mehmannavaz, R., Prasher, S., \& Ahmad, D. (2002). Rhizospheric effects of alfalfa on biotransformation of polichlorinated biphenyls in a contaminated soil augmented with Sinorhizobium meliloti. Process Biochemistry, 37(9), 955-963. doi:10.1016/ S0032-9592(01)00305-3.

Millioli, V. S., Servulo, E.-L. C., Sobral, L., \& de Carvalho, D. D. (2009). Bioremediation of crude oil-bearing soil: evaluating the effect of rhamnolipids addition to soil toxicity and to crude oil biodegradation efficiency. Global NEST Journal, 11(2), 181-188.

Muratova, A. Y., Dmitrieva, T. V., Panchenko, L. V., \& Turkovskaya, O. V. (2008). Phytoremediation of oil-sludge-contaminated soil. International Journal of Phytoremediation, 10(6), 486-502. doi:10.1080/15226510802114920.

Muratova, A. Y., Kapitonova, V., Chernyshova, M., \& Turkovskaya, O. V. (2009). Enzymatic activity of alfalfa in a phenanthrene-contaminated environment. World Acad Sci Eng Technol, 58, 569-574.

Nath, U. K., Wilmer, J. A., Wallington, E. J., Becker, H. C., \& Mollers, C. (2009). Increasing erucic acid content through combination of endogenous low polyunsaturated fatty acids alleles with Ld-LPAAT plus Bn-fael transgenes in rapeseed (Brassica napus L.). Theoretical and Applied Genetics, 118(4), 765-773. doi:10.1007/s00122-008-0936-7.

Nelson, E. B. (2004). Microbial dynamics and interactions in the spermosphere. Annual Review of Phytopathology, 42, 271309. doi:10.1146/annurev.phyto.42.121603.131041.

Nie, M., Wang, Y., Yu, J., Xiao, M., Jiang, L., Yang, J., et al. (2011). Understanding plant-microbe interactions for phytoremediation of petroleum-polluted soil. PLoS One, 6(3), e17961. doi:10.1371/journal.pone.0017961.

Nogueira, L., Inckot, R., Santos, G., Souza, L., \& Bona, C. (2011). Phytotoxicity of petroleum contaminated soil and bioremediated soil on Allophylus edulis. Rodriguesia, 62(3), 459-466.

Ogbo, E. M. (2009). Effects of diesel fuel contamination on seed germination of four crop plants-Arachis hypogaea, Vigna unguiculata, Sorghum bicolor and Zea mays. African Journal of Biotechnology, 8(2), 250-253.

Owsianiak, M., Szulc, A., Chrzanowski, L., Cyplik, P., Bogacki, M., Olejnik-Schmidt, A. K., et al. (2009). Biodegradation and surfactant-mediated biodegradation of diesel fuel by 218 microbial consortia are not correlated to cell surface hydrophobicity. Applied Microbiology and Biotechnology, 84(3), 545-553. doi:10.1007/s00253-009-2040-6.

Peng, S., Zhou, Q., Cai, Z., \& Zhang, Z. (2009). Phytoremediation of petroleum contaminated soils by Mirabilis Jalapa L. in a greenhouse plot experiment. Journal of Hazardous Material, 168(2-3), 1490-1496. doi:10.1016/j.jhazmat.2009.03.036.
Reed, M. L., \& Glick, B. R. (2005). Growth of canola (Brassica napus) in the presence of plant growth-promoting bacteria and either copper or polycyclic aromatic hydrocarbons. Canadian Journal of Microbiology, 51(12), 1061-1069. doi:10.1139/w05-094.

Reinhold-Hurek, B., \& Hurek, T. (2011). Living inside plants: bacterial endophytes. Current Opinion of Plant Biology, 14(4), 435-443. doi:10.1016/j.pbi.2011.04.004.

Reynoso-Cuevas, L., Gallegos-Martínez, M. E., Cruz-Sosa, F., \& Gutiérrez-Rojas, M. (2008). In vitro evaluation of germination and growth of five plant species on medium supplemented with hydrocarbons associated with contaminated soils. Bioresource Technology, 99(14), 6379-6385. doi:10.1016/j.biortech.2007.11.074.

Robert, F. M., Sun, W. H., Toma, M., Jones, R. K., \& Tang, C. S. (2008). Interactions among buffelgrass, phenanthrene and phenanthrene-degrading bacteria in gnotobiotic microcosms. Journal of Environmental Science and Health, Part A. Toxic/ Hazardous Substances and Environmental Engineering, 43(9), 1035-1041. doi:10.1080/10934520802059938.

Saharan, B., \& Nehra, V. (2011). Plant growth promoting rhizobacteria: a critical review. Life Sciences and Medicine Research, LSMR-21, 1-30.

Salanitro, J. P., Dorn, P. B., Huesemann, M. H., Moore, K. O., Rhodes, I. A., Rice Jackson, L. M., et al. (1997). Crude oil hydrocarbon bioremediation and soil ecotoxicity assessment. Environmental Science \& Technology, 31(6), 17691776. doi:10.1021/es960793i.

Sharifi, M., Sadeghi, Y., \& Akbarpour, M. (2007). Germination and growth of six plant species on contaminated soil with spent oil. International Journal of Environmental Science and Technology, 4(4), 463-470.

Sorkhoh, N. A., Ghannoum, M. A., Ibrahim, A. S., Stretton, R. J., \& Radwan, S. S. (1990). Crude-oil and hydrocarbondegrading strains of Rhodococcus-rhodochrous isolated from soil and marine environments in Kuwait. Environmental Pollution, 65(1), 1-17. doi:10.1016/0269-7491(90) 90162-6.

Tang, J., Wang, R., Niu, X., Wang, M., \& Zhou, Q. (2010). Characterization on the rhizoremediation of petroleum contaminated soil as affected by different influencing factors. Biogeosciences Discussions, 7(3), 4665-4688. doi:10. 5194/bgd-7-4665-2010.

Tesar, M., Reichenauer, T., \& Sessitsch, A. (2002). Bacterial rhizosphere populations of black poplar and herbal plants to be used for phytoremediation of diesel fuel. Soil Biology and Biochemistry, 34, 1883-1892. doi:10.1016/S00380717(02)00202-X.

Tyagi, M., da Fonseca, M. M., \& de Carvalho, C. C. (2011). Bioaugmentation and biostimulation strategies to improve the effectiveness of bioremediation processes. Biodegradation, 22(2), 231-241. doi:10.1007/s10532-0109394-4.

Van Hamme, J. D., Singh, A., \& Ward, O. P. (2003). Recent advances in petroleum microbiology. Microbiology and Molecular Biology Reviews, 67(4), 503-549. doi:10.1128/ mmbr.67.4.503-549.2003.

Wenzel, W. W. (2008). Rhizosphere processes and management in plant-assisted bioremediation (phytoremediation) of soils. Plant and Soil, 321(1-2), 385-408. doi:10.1007/ s11104-008-9686-1. 